\title{
Construction of Huawei's Image in News Reports: Take China Daily and The New York Times for Example
}

\author{
Kuizi Ma ${ }^{1} \&$ Ya Xiao ${ }^{1}$ \\ ${ }^{1}$ Department of Linguistics, School of International Studies, Zhejiang University, Hangzhou, China \\ Kuizi Ma and Ya Xiao contribute equally to this article. \\ Correspondence: Kuizi Ma, Department of Linguistics, School of International Studies, Zhejiang University, \\ Hangzhou, 310058, China. E-mail: makuizi1996@163.com
}

Received: March 1, $2020 \quad$ Accepted: April 6, $2020 \quad$ Online Published: April 11, 2020

doi:10.5539/ijel.v10n4p1 URL: https://doi.org/10.5539/ijel.v10n4p1

\begin{abstract}
In recent years, as China's largest smartphone company, Huawei's position in the international market has gradually increased and received widespread attention from foreign media. The rapid development of China's impact on the hegemony of the US has also changed the direction of US media's reporting on Chinese companies. At this stage, it is meaningful to study the image of Huawei in both Chinese and US media reports. Therefore, based on the corpus approach and critical discourse analysis, this paper builds two corpora of China Daily (576 reports with 438,261 words) and The New York Times (429 reports with 347,025 words). It is found that (1) both sides acknowledge that Huawei ranks top in world telecommunication technology, particularly in the 5G network; (2) two newspapers focus on different aspects in their reports. For the Chinese media, Huawei's technological prowess, innovation capacity in the global market, cooperation with many other European and African countries are given more attention, while for the American media, more focus is shifted to Huawei's threat to national security; (3) two newspapers hold different attitudes towards the rise of Huawei. China Daily's positive construction of Huawei's image is obvious. While for the American media, the Trump administration is more likely to project a threatening image of Huawei; (4) the reporting frameworks and the styles of materials selected differ in two newspapers. China Daily's framework concentrates on "Huawei" itself, while The New York Times tends to construct a reporting framework from multiple perspectives from the third-party.
\end{abstract}

Keywords: Huawei, trade war, critical discourse analysis, corpus linguistics

\section{Introduction}

The bruising economic and trade frictions between China and America have intensified since the Trump government extended the list of items to be tariffed in China in March 2018. On December 1, 2018, Meng Wanzhou, the chief financial officer of Huawei, the deputy chairwoman of Huawei's board, and the daughter of Huawei founder Ren Zhengfei, was detained when transferring flights in Canada. This detention was taken by the Canadian authorities on behalf of the United States, escalating U.S. restrictions on Huawei from the economic level to the political level. What's worse, as the world's largest producer of telecommunication equipment, Huawei maintains close business partnerships with many American companies like Google, Intel, Broadcomm, etc. However, soon after President Trump signed an executive order-"Securing the Information and Communications Technology and Services Supply Chain", Huawei Technologies Co. Ltd and its numerous partners were added to the Entity List by the US Commerce Department in Mid-May of 2018. Thus, the American companies were banned from providing technical support for Huawei and installing telecom equipment from Huawei. This series of events against Huawei is a very representative case in the context Sino-US trade war, which has aroused widespread attention from scholars at home and abroad.

In China, relevant studies were mainly focused on Huawei's adjustments in the areas of technology research and development (technology R \& D) as well as the business model in trade war. Tang, Zhou, and Hu (2019) applied the social network analysis method to construct the evolution path of Huawei's multinational R \& D network, illustrating the advantage of internalization strategy by cooperating with multiple foreign enterprises. Zhang (2019) studies the business model of Huawei on the basis of Osterwalder's nine elements theory, aiming to provide a model for domestic enterprises to deal with international trade conflicts. Meanwhile, Xia (2019) probes into the influence of US Export Laws and Regulations on China's new and high technology enterprises 
represented by Huawei, calling for the active use of legal weapons to defend the interests of enterprises and countries. On the other hand, foreign researchers seem to focus more on Huawei's tactical use of economic diplomacy in the trade war. Specifically, Pepermans (2016) explores the main characteristics of China's economic policy that exploit the weakness of the other. Bengtsson and Wang (2016) investigate Huawei's global supply chain strategies and balanced outsourcing practices, raising concerns that competition might overcome cooperation in this process. Haveman and Vochteloo (2016) even take the rise of Huawei to the political field by pointing out that the help Huawei received from the Chinese government might make it a national security threat, which actually has already been a hot topic in Chinese and American media reports.

Public opinions on the image of Huawei and China embodied in these media reports deserve particular attention since they not only are of great research value international communication, but also provide constructive suggestions for enhancing the voice of China and Chinese companies on the international stage. Two main categories can be generalized from the research focused on image construction in news reports. The first category was mainly on the media construction of the image of specific group. For example, Li and Zhang (2015) discovered that Chinese women were often shaped as "passive", "weak", and "inferior" group based on 12 news reports selected from the mainstream western newspapers published around the Women's Day. Ren (2015) found a strong tendency of rendering the negative image of Chinese tourists by analyzing the structure and intertextuality of a news report from New York Times. The second category shed light on the construction of China's national image. In detail, Gao (2012) examined US media's construction of China's image during the closing period of Olympic games based on news reports from The New York Times and Washington Post. Similarly, Liu and Yu (2014) employed the self-built corpus of British major media's reports on China after the Olympic game and analyzed the image of China projected from the perspective of discourse analysis. Particularly, some researchers also utilized the news reports on representative Chinese corporates to speculate the image construction of China. Li (2014) selected two news reports on Huawei from the Economist, attempting to reveal the hidden ideological tendencies in Western media and to reflect how the external image of Chinese companies and China were affected by the media. Zuo (2019) explored how the image of Huawei and China changed through the comparison between American news reports on Huawei before and after the strategy transition of Huawei in 2016. However, relevant studies were mainly from the western side, and few studies have looked at this issue from a comprehensive viewpoint in light of news reports from home and abroad. Though, Ji, Dong and Li (2019) did examine the spreading speed of the event "Huawei sues the US government" on Weibo and WeChat, two main social media platforms in China, neither the image of the corporate nor the government is clearly displayed. Therefore, to fill this research gap, this study builds a corpus of Chinese and American media reports centering on the Huawei issue. Under the framework of critical discourse analysis, a quantitative analysis is combined with qualitative illustration to inquire into the differences in perceptions and discourse construction between the two sides and to further explore the political intentions behind these reports. Particularly, two questions will be answered throughout this study (1) What are the similarities and differences between Chinese and American corpora in terms of co-occurrence networks, high-frequency words and concordance lines? (2) What lies behind these similarities and differences in the social-cultural context?

\section{Method and Materials}

Fairclough (1995) propounded a critical theory that regards language use as a form of social practice, based on which the approach of Critical Discourse Analysis (CDA) came into being. Perceiving language interaction as both socially shaped and socially constitutive, CDA explores how power, dominance and ideology are represented in language (Wodak et al., 2015). In this case, CDA is not a discrete academic discipline but a problem-oriented interdisciplinary research field. CDA has been highly recognized and extensively applied in social science due to its solid theoretical foundation and strong analytical method. The meaning of the term "critical" has been widely considered self-explanatory in much CDA theory to date, while it can be interpreted from contrasting perspectives in different social-cultural contexts. In western countries, the meaning of critique can be traced back to ancient Greece, through the Enlightenment philosophers to modern times, which refers to questioning common set of views or mainstream ideology in a rational way in CDA, the use of this term is largely influenced by Marxist and later Frankfurt School critical theory, in which critique is seen as a mechanism for explaining and changing social phenomena. Currently, the notion of critique is used in a borderer sense, which means the practice that combines "social and political engagement" with "a sociologically informed construction of society". Therefore, CDA refers to the generation and transmission of critical knowledge enabling human beings to free themselves from domination by means of self-pursuit. The core of critique is the relationship between discourse and social structure. Namely, the purpose of critical social research is to help solve today's social errors (including, in a broader sense, injustice, inequality, lack of freedom, etc.) by probing 
into their sources and causes, resistance to them and possibilities of overcoming them.

A large number of traditional CDA tends to highlight the analyses of limited texts in light of the textual features evident on close reading. The interpretations may encounter problems like representativeness and generalizability (Lischinsky, 2011), thus being criticized for the subjective selection of language materials for the sake of confirming the researchers' biases (Widdowson, 1995). Baker et al. first broadened the research framework of CDA by introducing the Corpus Linguistic Approach, providing supplementary linguistic devices for more in-depth analysis. As a data-driven method, this corpus-based approach has several merits. Specifically, it allows the database of researchers to encompass much more language materials with the aid of corpus techniques. Under this circumstance, as Widdowson proposed, it contributes to the reduction of researchers' biases. Most importantly, the frequency of particular words and phrases, the concordance networks, as well as the diversity of language use can be accurately computed through the corpus linguistic software, which not only provides data-supported quantitative analysis results, but also paves the way for the researchers to examine the collocational environments, salient patterns as well as the discourse functions in a well-founded way (Wodak et al., 2011).

Newspaper, as a type of speech, is believed to have a wider readership base and more clearly represent how "Huawei" is described. Given the key role that mass media play in constructing social identity, a corpus-based discourse analysis of newspaper articles would appear to be a suitable starting point. China Daily is the largest English portal that provides news, business information and learning materials in China, and The New York Times is an American newspaper based in New York City with worldwide influence and readership.

The research procedure consists of three steps. First, data collecting. The present materials were extracted from China Daily and The New York Times in "Lexis Advance" database, the world's largest electronic database for electronic and journalistic documents, by limiting the key term "Huawei", all of which are reported from December 1st, 2018 when Meng Wanzhou was detained when transferring flights in Canada to December 1st, 2019 based on the time period of the event concentration, limited to a complete natural year (12 months).

In the two corpora, the number of Chinese reports in China Daily reached 576 with a total of 438,261 words, and the number of American reports was 429 with 347,025words in total.

Table 1. Basic information of reports in the two media

\begin{tabular}{llll}
\hline Media category & Number of reports & Number of words & Average number \\
\hline China Daily & 576 & 438,261 & 760 \\
The New York Times & 429 & 347,025 & 808 \\
\hline
\end{tabular}

Second, data encoding and processing, the collected news texts were processed by two corpus linguistic tools, namely KH Coder and AntConc 3.5.8. KH Coder is a quantitative analysis software and serves to make co-occurrence networks of "Huawei" in two corpora. AntConc was employed to investigate the high-frequency words and concordance lines of "Huawei". Last, data analyzing. The analysis of co-occurrence networks, high-frequency words and concordance lines meant to reveal how Huawei's image is constructed in Chinese and US media and what diachronic social factors might exert the construction.

\section{Results}

\subsection{Co-Occurrence Networks Analysis}

Textual analysis starts with an investigation into the co-occurrence networks of "Huawei" in two corpora. Co-occurrence network is the collective interconnection of terms based on their paired presence within a specified unit of text, which is generally used to provide a graphic visualization of potential relationships between words, concepts or other entities represented within written material or context. According to Baker (2006), the co-occurrence network could highlight certain relevant phenomena within the data and 'help to give the user a sociological profile of a given word or phrase enabling greater understanding of its use in particular contexts'.

The co-occurrence network of "Huawei" in China Daily and The New York Times was generated by KH Coder, a free software designed for quantitative content analysis and text mining. The clustering in the co-occurrence networks represents the main terms that have close connections to the key term "Huawei". The size of clusters reflects the frequency of certain term, and the biggest circle represents 3000 more occurrences of one word. The solid lines in the networks refer to the direct relationship between words in certain clusters. The dashed lines 
represent less close relation between words in certain clusters. To understand the high frequency collocations of "Huawei", the co-occurrence network diagrams of "Huawei" in two media shown in Figures 1 and 2 were autonomously generated by $\mathrm{KH}$ Coder, and the functional words such as prepositions and pronouns were eliminated.

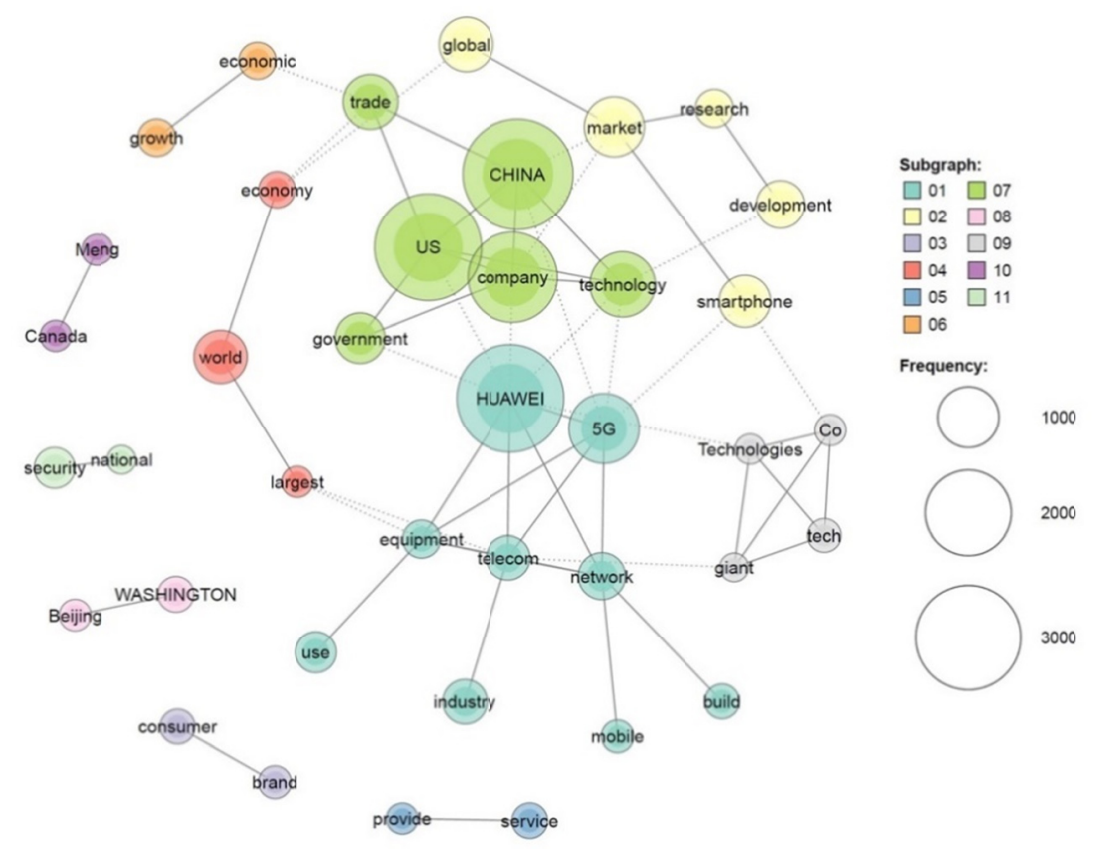

Figure 1. Co-occurrence network of Huawei in China Daily

As is shown in Figure 1, the collected news reports in China Daily mainly concentrate on the following major collocations with reference to "Huawei": "US", "trade", "technology company", and "5G industry". This finding suggests that Huawei is viewed as a giant company in $5 \mathrm{G}$ technology and telecom industry with advanced equipment and network in Chinese media. The dashed line between "trade" and "world economy", "economic growth", "global market" and "tech giant" indicates that Huawei's development is also related to world economic growth and global market as a tech giant as well. 


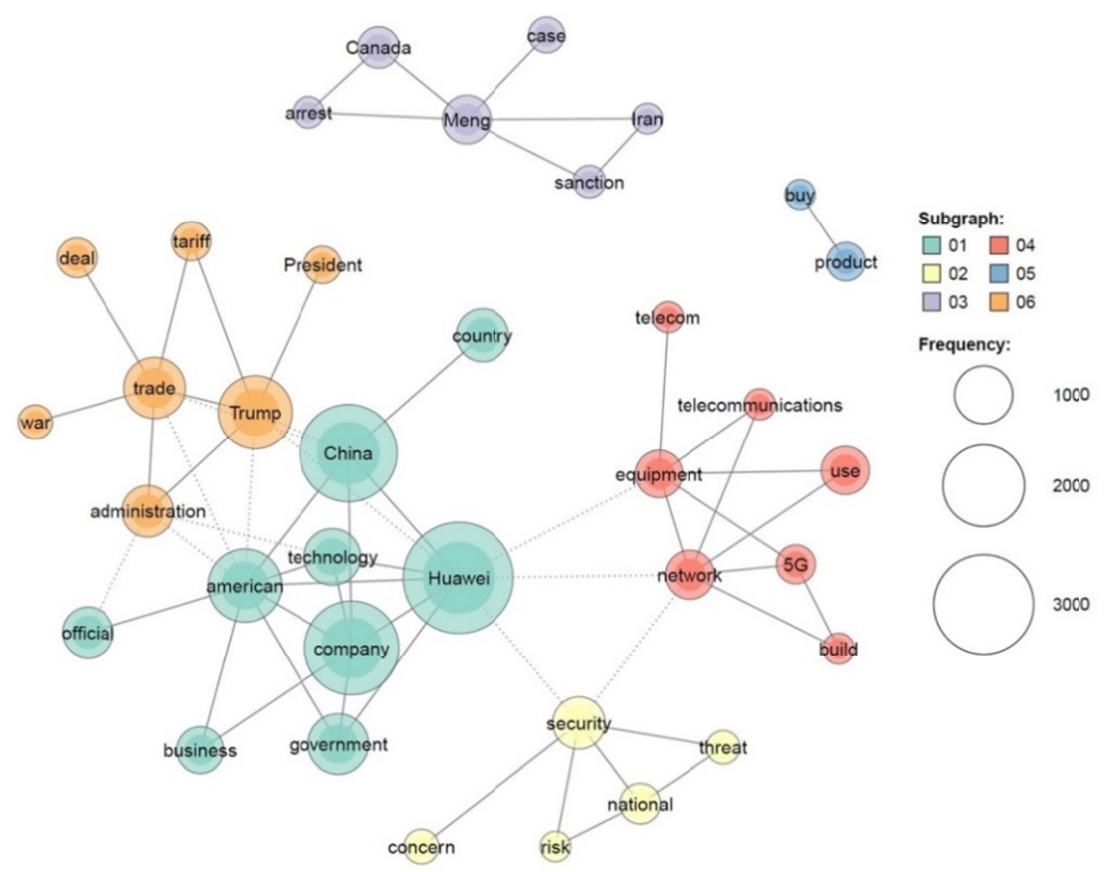

Figure 2. Co-occurrence network of Huawei in The New York Times

In Figure 2, Huawei is closely connected to the collocations like "technology company", "business", "Trump administration", "trade war", "tariff". It can be seen that while the US media recognize Huawei's position in 5G technology and telecommunications, they have focused more on the "trade war" and "tariff" with China. The dashed line also indicates that Trump administration regarded Huawei as a big "threat" and "risk" to national security and also as a bargaining chip in the trade war with China. Besides, US media also reported a lot about their sanctions on Huawei since Canada detained Meng Wanzhou.

\subsection{High-Frequency Words Analysis}

High-frequency word is a basic indicator used in corpus linguistics. The first stage of the analysis of the data is a study of the raw frequency of non-function words, which according to Baker (2006) may highlight certain relevant phenomena within the data and 'can help to give the user a sociological profile of a given word or phrase enabling greater understanding of its use in particular contexts' (p. 47).

Owing to the large size of the "Huawei" corpus, extracting high-frequency words from the whole corpus assisted by AntConc can be reasonably expected to include a large number of representative terms, that is, words that most frequently appear in many news reports. Since this study mainly focuses on the semantic level, only the top 20 notional high-frequency words in two corpora were discussed in detail, as shown in Table 2.

Table 2. Top 20 notional high-frequency words in China Daily and The New York Times

\begin{tabular}{|c|c|c|c|c|c|c|}
\hline \multicolumn{4}{|c|}{ China Daily } & \multicolumn{3}{|c|}{ The New York Times } \\
\hline Rank & Freq & Word & Normalized Freq & Freq & Word & Normalized Freq \\
\hline 1 & 3617 & China & 8.253 & 3763 & Huawei & 10.844 \\
\hline 2 & 3192 & Huawei & 7.283 & 2936 & China & 8.460 \\
\hline 3 & 985 & technology & 2.248 & 1741 & American & 5.017 \\
\hline 4 & 911 & trade & 2.079 & 1622 & Trump & 4.674 \\
\hline 5 & 877 & world & 2.001 & 1223 & trade & 3.524 \\
\hline 6 & 819 & market & 1.869 & 934 & security & 2.691 \\
\hline 7 & 668 & new & 1.524 & 882 & technology & 2.542 \\
\hline 8 & 636 & development & 1.451 & 724 & new & 2.086 \\
\hline 9 & 628 & government & 1.433 & 696 & Meng & 2.006 \\
\hline 10 & 519 & security & 1.184 & 550 & network & 1.585 \\
\hline 11 & 473 & cooperation & 1.079 & 542 & against & 1.562 \\
\hline 12 & 434 & research & 0.990 & 391 & war & 1.127 \\
\hline 13 & 381 & network & 0.869 & 387 & tariffs & 1.115 \\
\hline 14 & 290 & against & 0.662 & 322 & ban & 0.928 \\
\hline
\end{tabular}




\begin{tabular}{|c|c|c|c|c|c|c|}
\hline 15 & 274 & European & 0.625 & 308 & global & 0.888 \\
\hline 16 & 268 & investment & 0.612 & 304 & sanctions & 0.876 \\
\hline 17 & 255 & giant & 0.582 & 284 & concerns & 0.818 \\
\hline 18 & 211 & interests & 0.481 & 277 & laws & 0.798 \\
\hline 19 & 205 & efforts & 0.468 & 267 & giant & 0.769 \\
\hline 20 & 204 & competition & 0.465 & 256 & threat & 0.738 \\
\hline
\end{tabular}

Table 2 displays the top 20 notional normalized high-frequency words in the news reports about "Huawei" selected from China Daily and The New York Times. As listed, the two newspapers have 10 identical high-frequency words although the raw frequency and percentage within each corpus differ, i.e., "Huawei", "China", "trade", "security", "technology", "new", "network", "against", "global", and "giant". It can be inferred that against the backdrop of intensified trade frictions between China and the United States, what lies behind the development of Huawei is an economic, political, technological issue of global concern. Although both sides acknowledge Huawei as a giant, the security problem has aroused common attention. As an influential and representative Chinese enterprise, Huawei's image also reflects China's national image.

It ought to be noted that Chinese media and American media obviously have shown different attitudes when reporting. In particular, words such as "market", "develop", "cooperation", "government", "research", "European", "investment", "interests", "efforts" and "competition" were unique to the Chinese corpus while words like "American", "Trump", "Meng", "war", "tariff", "ban", "sanctions", "concerns", "laws" and "threat" were only included in the American corpus.

\subsection{Concordance Lines}

Concordance is the list of all the occurrences of a particular search term in a corpus, also referred to as key word in context. The statistical analysis of concordance is the basic part of corpus linguistics, which can provide more contextual information about "company that a word keeps" with different collocations for discourse analysis (Biber et al. 1998). Words or phrases are said to have a negative or positive semantic prosody if they typically co-occur with units that have a negative or positive meaning in their concordance lines (McEnery and Hardie, 2012). This study chooses "Huawei" as a search word to make the concordance lines in two newspapers (3192 concordance lines in China Daily and 3763 concordance lines in The New York Times) and randomly extract 10 sample lines of each corpora to list as follows.

Table 3. Sample Concordance lines of Huawei in China Daily

\begin{tabular}{|c|c|c|c|}
\hline \multicolumn{4}{|c|}{ China Daily } \\
\hline 1 & Is telecommunications equipment provider & Huawei & $\begin{array}{l}\text { a private company seen as a symbol of China's } \\
\text { technological prowess. }\end{array}$ \\
\hline 2 & $\begin{array}{l}\text { saying she and her company have violated US } \\
\text { sanctions on Iran. But }\end{array}$ & Huawei & $\begin{array}{l}\text { a leading Chinese telecommunications and } \\
\text { high-tech company }\end{array}$ \\
\hline 3 & thanks to economic globalization, & Huawei & $\begin{array}{l}\text { and China's high-tech industry has become } \\
\text { bargaining chips. }\end{array}$ \\
\hline 4 & $\begin{array}{l}\text { guided by political considerations and tactics, } \\
\text { not by the rule of law. }\end{array}$ & Huawei & expressed confidence in Meng's innocence. \\
\hline 5 & Following Friday's announcement, & Huawei & $\begin{array}{l}\text { expressed disappointment over Canada's } \\
\text { approval of the extradition }\end{array}$ \\
\hline 6 & Hongmeng was born at a time when & Huawei & $\begin{array}{l}\text { faces a crisis because even today the company } \\
\text { still faces sanctions }\end{array}$ \\
\hline 7 & made a concession and knew that banning & Huawei & harms the US tech companies' interests. But \\
\hline 8 & global cooperation and partnership," he said. & Huawei & $\begin{array}{l}\text { has joined more than } 400 \text { standards } \\
\text { organizations. }\end{array}$ \\
\hline 9 & of the company was detained in Canada. & Huawei & $\begin{array}{l}\text { has signed } 5 G \text { network contracts with over } 20 \\
\text { countries, }\end{array}$ \\
\hline 10 & $\begin{array}{l}\text { the secretary-general of the Mobile China } \\
\text { Alliance, said }\end{array}$ & Huawei & $\begin{array}{l}\text { is a global pioneer in research and development } \\
\text { for } 5 G \text { telecom equipment. }\end{array}$ \\
\hline
\end{tabular}

Note. Words that require special attention in the concordance lines were italicized, as these words intuitively reflected different attitudes of the American and Chinese media in reporting. 
Taking the China Daily corpus first, the word "Huawei" is mostly found in a positive environment. About three in five concordances of "Huawei" are followed by the preponderance description of Huawei's leading and giant position in 5G technology and its cooperation with many other countries, i.e., "a symbol of China's technological prowess", "a leading Chinese telecommunications and high-tech company". Two in five express Huawei's disappointment over Canada's extradition and US sanction and show their confidence in the prospects of the future.

Table 4. Sample Concordance lines of Huawei in The New York Times

\begin{tabular}{|c|c|c|c|}
\hline \multicolumn{4}{|c|}{ The New York Times } \\
\hline 1 & Whether the government should allow & Huawei & a Chinese company considered a security risk \\
\hline 2 & Many of the chip innovators of & Huawei & $\begin{array}{l}\text { are a key target of the Trump administration in } \\
\text { the trade war }\end{array}$ \\
\hline 3 & $\begin{array}{l}\text { Much of Mr. Trump's focus has been on the next } \\
\text { generation of wireless technology, known as } 5 G \text {. } \\
\text { But }\end{array}$ & Huawei & $\begin{array}{l}\text { already provides equipment to about a quarter } \\
\text { of the country's smallest wireless carriers. }\end{array}$ \\
\hline 4 & $\begin{array}{l}\text { national security threat, and American officials } \\
\text { have been warning allies for months that the } \\
\text { United States will stop sharing intelligence if they } \\
\text { use }\end{array}$ & Huawei & $\begin{array}{l}\text { and other Chinese technology to build the core } \\
\text { of their } 5 G \text { networks. }\end{array}$ \\
\hline 5 & $\begin{array}{l}\text { The U.S. has been pushing its Western allies to } \\
\text { ditch }\end{array}$ & Huawei & $\begin{array}{l}\text { a company that it claims Beijing uses for } \\
\text { espionage. }\end{array}$ \\
\hline 6 & $\begin{array}{l}\text { In November, after British officials raised } \\
\text { questions with }\end{array}$ & Huawei & $\begin{array}{l}\text { the company pledged to spend } \$ 2 \text { billion over } \\
\text { the next five years to improve its software and } \\
\text { security processes. }\end{array}$ \\
\hline 7 & $\begin{array}{l}\text { The Polish authorities arrested two people, } \\
\text { including a Chinese employee of the } \\
\text { telecommunications giant }\end{array}$ & Huawei & and charged them with spying for Beijing \\
\hline 8 & $\begin{array}{l}\text { The United States has questions about links } \\
\text { between }\end{array}$ & Huawei & $\begin{array}{l}\text { and Chinese security agencies and the } \\
\text { People's Liberation Army. }\end{array}$ \\
\hline 9 & $\begin{array}{l}\text { American officials frequently point out that the } \\
\text { founder of }\end{array}$ & Huawei & $\begin{array}{l}\text { Ms. Meng's father, Ren Zhengfei, was a } \\
\text { soldier decade ago in the People's Liberation } \\
\text { Army. }\end{array}$ \\
\hline 10 & $\begin{array}{l}\text { We will not compromise on the improvements we } \\
\text { need to see from }\end{array}$ & Huawei. & l \\
\hline
\end{tabular}

Note. Words that require special attention in the concordance lines were italicized, as these words intuitively reflected different attitudes of the American and Chinese media in reporting.

As shown in Table 4, in the ten randomly selected concordance lines which we took from The New York Times, only one-tenth concordances of "Huawei" is about Huawei's quick development in $5 \mathrm{G}$ networks, the left nine lines of reports all indicate a negative discourse environment that American officials regard Huawei as a big threat and risk to American security and try to find allies to boycott it.

\section{Discussion}

\subsection{Co-Occurrence Networks}

According to the co-occurrence networks of Huawei in two corpora, both newspapers have a consistent principle of the construction of Huawei's image, which reflects their reporting orientation based on different national interests.

For example, China Daily has consistently demonstrated Huawei's leading position in world telecommunications especially its $5 \mathrm{G}$ technology, and also the country's support for Huawei and independently built a positive image of China.

The New York Times pay much more attention to the intertextuality and corroboration of multiple positions and try to achieve the "objectivity" of the report as much as possible, and "naturally" convince readers to accept the reality and concepts constructed by the media, but its framework is still closely related to its national position. The battle around Huawei is not just for US telecommunication security. Washington believes the rise of Huawei signals China's attempt to take global technological and economic leadership from the United States. The co-occurrence networks further indicate the US's concern for the rise of Huawei and China in the world. 


\subsection{High-Frequency Words}

The 10 overlapping high-frequency words (China, Huawei, technology, trade, new, government/Trump, security, network, against, giant) reflect the consensus of two countries towards Huawei. Specifically, both two media recognize Huawei's position in world telecommunication especially in 5G technology as a Chinese tech giant, because "China" and "Huawei" rank the top 2 in two corpora. In the meanwhile, the two newspapers also put much emphasize on Huawei's role in trade and national security.

The different high-frequency words in the Chinese and American corpus respectively reflect on the differences in their focuses on reports. In the corpus of China Daily, Chinese media focus more on the description of Huawei's technology which is pushing ahead with the commercialization of 5G technology as a global leader. "Cooperation" is another keyword in Chinese media. Huawei launches economic and technological cooperation with many European and African countries along the Belt and Road to promote mutual benefit and win-win results, which has been revealed in previous studies (Pepermans \& Astrid, 2016).

While for the American media, the Trump administration raises concern over the rise of Huawei and thinks of it as a threat. Under this circumstance, even a whole year has passed since the incident of Meng Wanzhou, this event still remains being widely reported by American media. Meanwhile, the tariff barriers, as well as legal sanctions aiming to ban Huawei from being further entering into the American market, are the core of media coverage.

\subsection{Concordance Lines}

In general, China Daily's positive construction of Huawei's image is obvious and focused. Most of them based on factual descriptions and supplemented by standpoints and views, which comprehensively show Huawei's technological prowess and innovation capacity in the $5 \mathrm{G}$ technology. When referring to "Huawei", it is often accompanied by collocations such as "Chinese enterprises" and "domestic smartphone", which reflects the "Chinese wisdom" and "Chinese technological innovation". The self-reports of Huawei and China are relatively tough, highlighting the defense of Chinese interests and fighting back the US sanction; although many countries have come under great pressure from the United States to ban Chinese telecom equipment company Huawei from their $5 \mathrm{G}$ networks, most of them have rejected a blanket ban on Huawei products.

Clearly, the American media fear the rise of Huawei, which can be seen from their use of phrases like "security risk" and "security threat" when talking about Huawei, and the Trump government has regarded Huawei as a "key target" in the trade war.

As Wodak et al. (2015) mentioned, critical discourse analysis explores how power, dominance and ideology are represented in language, thus social context where text and discourse practice occur is an important aspect for exploring the underlying social factors of the image construction at the macro level in CDA. It's clear that two media have different focuses in their reports though American media also recognized Huawei's technological prowess and innovation capacity in the $5 \mathrm{G}$ technology. The social context shows that Huawei has made enormous progress in developing chips, which cracks down on American monopoly on Chinese chip market. Additionally, Huawei's current 5G technology can be said to be at the forefront of the world, seizing quite a lot of market share from America in the next generation of wireless technological innovation, which has brought huge pressure to America.

There are also political reasons in social context for America's concern. Specifically, 5G equipment is the foundation of the current network. It is true that the country that provides the network equipment gets the most intelligence. In this case, American media constantly "question" the political intention of Huawei's expansion in the international market by accusing Huawei of maintaining close ties to the "People's Liberation Army" and conducting "espionage" or "spying" for the Beijing government. As a result, America has begun a series of suppressions on Huawei and tried every means to prevent Huawei from entering the US market. Not only that, but America is also cooperating with other European countries to suppress Huawei and attempt to justify its trade hegemonic practices by citing measures taken by its "western allies". Through the concordance lines formed by a large percentage of explicit negative vocabulary, the worry about, as well as the repression against Huawei from the American side, are as clear as daylight, and by no means will they "make compromise", which is consistent with previous studies (Zuo, 2019).

\section{Conclusions}

This study applies the Critical Discourse Analysis method to explore the construction of Huawei's image in the self-built corpus of reports, which are extracted from China Daily and The New York Times. Through comparing and analyzing the co-occurrence networks, the high-frequency words and the concordance lines, this study 
interprets the different construction of Huawei in two media and the intentions behind it. Major findings are as follows:

First, both Chinese and American media have acknowledged that Huawei is a tech giant in world telecommunication technology especially in 5G network. Second, two media have different focuses in their reports. Chinese media focuses on Huawei's technological prowess, innovation capacity in the global market, cooperation with many other European and African countries; while American media on Huawei's threat to national security. Third, Chinese and American media hold different reporting attitudes. China Daily's positive construction of Huawei's image is obvious and focused. While for the American media, the Trump administration raises concern over the rise of Huawei and thinks of it as a threat. Fourth, the Chinese and American media hold different reporting frameworks and styles of selecting materials. China Daily's framework mostly focuses more on "Huawei" itself, while The New York Times constructs a reporting framework from multiple perspectives like other countries and organizations. In selecting materials, both newspapers selectively highlight different events. For example, American media emphasized the storm of China's arrest of Canadians, while the Chinese side paid more attention to Meng Wanzhou's arrest. The coverage of the two newspapers is partly ideologically based on their national political positions.

\section{References}

Baker, P., Gabrielatos, C., KhosraviNik, M., Krzyżanowski, M., McEnery, T., \& Wodak, R. (2008). A useful methodological synergy? Combining critical discourse analysis and corpus linguistics to examine discourses of refugees and asylum seekers in the UK press. Discourse \& Society, 19(3), 273-306. https://doi.org/10.1177/0957926508088962

Baker, P., Hardie, A., \& McEnery, T. (2006). A Glossary of Corpus Linguistics. Edinburgh University Press.

Fairclough, N. (1995). Discourse and Social Change. Cambridge, UK: Policy.

Gao, Y. (2012). Discursive construction of national image of China in American broadsheets: A study of critical discourse analysis assisted by methods of corpus linguistics. Master's thesis. Available from CNKI Dissertation and Theses database. Retrieved from http://kreader.cnki.net/Kreader/CatalogViewPage.aspx?dbCode=cdmd\&filename=1013107870.nh\&tablena $\mathrm{me}=$ CMFD201301\& compose $=\&$ first $=1 \&$ uid $=$ WEEvREcwSIJHSldRa1FhcTdnTnhXY3JjWWRCOHJNM3 1QaDFXUUFTUlpEUT0=\$9A4hF_YAuvQ5obgVAqNKPCYcEjKensW4IQMovwHtwkF4VYPoHbKxJw

Ji, Y. N., Dong, X., \& Li, S. H. (2019). A preliminary study of Sina Weibo's online public opinions on the event of Huawei suing US government. Press Outpost, 10, 96-97. Retrieved from https://kns.cnki.net/KCMS/detail/detail.aspx?dbcode=CJFQ\&dbname=CJFDLAST2019\& filename=XYQS 201910055\&v=MDc2NjFyQ1VSN3FmWk9ScUZ5RGxVTHpPUFRUYWZiRzRIOWpOcjQ5QVIZUjhlW DFMdXhZUzdEaDFUM3FUcldNMUY=

Lars, B., \& Wang, W. H. (2016). Cost innovation in global supply chains: The case of Huawei Technologies. International Journal of Logistics Systems and Management, 23(2), 539-557. https://doi.org/10.1504/IJLSM.2016.073969

Li, N., \& Zhang, Q. (2015). A corpus-based critical discourse analysis of the Chinese women's media image in major western newspapers. Journal of Shanxi Normal University (Social Science Edition), 42(6), 105-110. https://doi.org/10.16207/j.cnki.1001-5957.2015.06.023

Li, Y. H. (2014). The external image of Chinese enterprises from the Western media's news reports-from the perspective of critical discourse analysis. News Research, 3, 105-106. https://doi.org/CNKI:SUN:XWZS.0.2014-03-044

Lischinsky, A. (2011). In times of crisis: A corpus approach to the construction of the global financial crisis in annual reports. Critical Discourse Studies, 8(3), 153-168. https://doi.org/10.1080/17405904.2011.589231

Liu, C. (2018). A contrastive study of generic intertextuality on the disputes over the South China Sea between Chinese and American media-Take People's Daily and The New York Times for example. PhD Dissertation. Nanjing Normal University, China. Available from CNKI Dissertation and Theses database. Retrieved from https://kns.cnki.net/KCMS/detail/detail.aspx?dbcode $=$ CDFD\&dbname $=$ CDFDLAST2018\& filename $=1018$ 262247.nh\&uid=WEEvREcwSIJHSldRa1FhdkJtNEYxR1BEelNEdU55bXdOL2RTVWZsNmFMST0=\$9A 4hF_YAuvQ5obgVAqNKPCYcEjKensW4ggI8Fm4gTkoUKaID8j8gFw!!\&v=MTIzNzViUEISOGVYMUx 1eFITN0RoMVQzcVRyV00xRnJDVVI3cWZaT1JxRnlEbVViclBWRjI2RnJHK0hOUElxSkU=

Liu, J., \& Yu, Y. (2014). A corpus-based discourse analysis of media discourse: The construction of Chinese 
national image by British media after the Olympic Games. Journal of Dalian Maritime University (Social Science Edition), 13(6), 111-115. https://doi.org/CNKI:SUN:DLHX.0.2014-06-025

McEnery, T., \& Hardie, A. (2012). Corpus Linguistics: Method, Theory and Practice. Cambridge University Press. https://doi.org/10.1017/CBO9780511981395

Michelle, H., \& Jeroen, V. (2016). Huawei: A Case Study on a Telecom Giant on the Rise. In R. Segers (Ed.), Multinational Management: A Casebook on Asia's Global Market Leaders (pp. 75-94). New York: Springer International Publishing Switzerland. https://doi.org/10.1007/978-3-319-23012-2_5

Pepermans, A. (2016). The Huawei case and what it reveals about Europe's trade policy. European Foreign Affairs Review, 21(4), 539-558. $\quad$ Retrieved from https://www.kluwerlawonline.com/document.php?id=EERR2016043

Ren, J., Ding, Y. P., \& Liu, M. (2015). Interpretation of the image of Chinese tourists in the framework of critical discourse analysis: A case study of a New York Times report. Overseas English, 5, 220-226. Retrieved from http://kns.cnki.net/KXReader/Detail?TIMESTAMP=637205092867828750\&DBCODE=CJFQ\&TABLENa $\mathrm{me}=$ CJFDLAST2015\&FileName $=$ HWYY201505109\&RESULT $=1 \& S I G N=k$ fandyNmRD4M1 VPGNuZfg $80 Y 480 \% 3 d$

Tang, Y. L., Zhou, X. L., \& Hu, X. (2019). The evolution of the role of R \& D units in multinational R \& D networks-Take Huawei's case for example. Technology Economics, 38(8), 10-17.

Widdowson, H. G. (1995). Discourse analysis: A critical view. Language and Literature, 4(3), 157-172. https://doi.org/10.1177/096394709500400301

Wodak, R., \& Michael, M. (2015). Methods of Critical Discourse Studies. London: SAGE Publications.

Xia, M. Y. (2019). Analysis of the influence of US strengthening export control on high-tech enterprises in China as well as China's countermeasures. Journal of Chengdu Institute of Public Administration, 124, 57-61. Available from CNKI Dissertation and Theses database. Retrieved from http://kns.cnki.net/KXReader/Detail?TIMESTAMP=637207675610557500\&DBCODE=CJFQ\&TABLENa $\mathrm{me}=$ CJFDLAST2019\&FileName $=$ CDXZ201904012\&RESULT $=1 \&$ SIGN=IViHvitttzzvnmkGifij01 mSLB0 $\% 3 \mathrm{~d}$

Zhang, X. J. (2019). Perspective on the business model composition of China Huawei. Value Engineering, 38(17), 228-231. https://doi.org/10.14018/j.cnki.cn13-1085/n.2019.17.088

Zuo, M. Y. (2019). Research on corporate image transformation of Huawei in US media reports. Modern Marketing, 8, 78-80. Available from CNKI Dissertation and Theses database. Retrieved from https://kns.cnki.net/KCMS/detail/detail.aspx?dbcode $=$ CJFQ\&dbname $=$ CJFDLAST2019\&filename $=$ XIXJ2 01908061\&uid=WEEvREcwSlJHSldRa1FhdkJtNEYxR1BEelNEdU55bXdOL2RTVWZsNmFMST0=\$9A 4hF_YAuvQ5obgVAqNKPCYcEjKensW4ggI8Fm4gTkoUKaID8j8gFw!!\&v=MTYwOTdZUjhlWDFMdX hZŪzdEaDFUM3FUcldNMUZyQ1VSN3FmWk9ScUZ5RG1XcjNMUFNUVFpMRzRIOWpNcDQ5RFo=

\section{Copyrights}

Copyright for this article is retained by the author, with first publication rights granted to the journal.

This is an open-access article distributed under the terms and conditions of the Creative Commons Attribution license (http://creativecommons.org/licenses/by/4.0/). 